\title{
Yerel Yönetimlerin Yoksullukla Mücadeledeki Yeri: Küresel Düzeyden Yerel Düzeye Yeni Yönelimler
}

\section{Local Government in the Struggle against Poverty: New Trends from Global to Local}

\section{Ali Yeşildal' ${ }^{1}$}

\section{Öz}

Birleşmiş Milletler Kalkınma Programına (UNDP) göre dünya genelinde yaklaşık bir milyar insanın aşırı yoksulluk koşullarında günde bir doların altında yaşadığı, temel beşeri ihtiyaçlarını karşılayamadığı ve en az bir milyar insanın da göreceli yoksulluk koşullarında yaşadığı tahmin edilmektedir. Bu, dünyadaki çocukların üçte birinden fazlasının yetersiz beslendiği, yarısından çoğu kadın olmak üzere 840 milyondan fazla yetişkinin okuma yazma bilmediği, 1.2 milyon insanın güvenli içme suyuna erişimi olmadan yaşadığı anlamına gelmektedir. Küresel yoksulluğa ilişkin bu acı tablo, yoksulluğun günümüzde belki daha önceleri hiç olmadığı kadar kronik bir sorun haline geldiğini açıkça göstermektedir. Bu duruma bağlı olarak, son zamanlarda yoksullukla mücadelede yerel yönetimler daha sık gündeme gelmektedir. Nitekim çeşitli nedenlerden dolayı yerel yönetimlerin yoksullukla mücadelede etkin bir görev alabilmesi mümkün görünmektedir. Bununla birlikte, yerel yönetimler, genellikle, yoksulluk nedenlerini belirlemek, müdahalelere öncelik vermek veya yoksulların belirli gruplarını hedef alan veri ve bilgilerden yoksundur. Daha önce merkezi planlama ile görevlendirilen yerel yönetimler, yerel kalkınma planlarının hazırlanması ve uygulanmasında çok az deneyime sahiptir. Yetersiz yetki devri, kaynakların orantısız dağıtılması veya sektörler arasında koordinasyonun zayıf olması, yerel yönetimlerin yoksullukla mücadele kapasitelerini daha da kısıtlamıştır. Sınırlı aşağı doğru hesap verebilirlik, yeni yetkilendirilmiş makamların siyasi iradesinin harekete geçmesini de sınırlamıştır. Bu gibi nedenlerle bu çalışma, yerel yönetimlerin yoksullukla çok boyutlu bir mücadelenin ancak bileşenlerinden biri olabileceğini savunmakta; sürdürülebilir ve kalıcı etkilerin ancak ve ancak merkezi politika ve müdahaleleri başarıyla tamamlayabildiklerinde söz konusu olabileceğini ileri sürmektedir. Nitekim küreselleşme süreciyle birlikte, gittikçe daha da derinleşen ve kalıcı hale gelen yoksulluk sorunu, bu tür bir iş bölümünü daha da gerekli kılmaktadır.

\section{Anahtar Kelimeler}

Yoksulluk, Yoksullukla mücadele, Yerel yönetimler, Küreselleşme, Yerelleşme

1 Sorumlu Yazar: Ali Yeşildal (Dr.), Kocaeli Büyükşehir Belediyesi, Kocaeli, Türkiye. E-posta: ayesildal41@gmail.com ORCID: 0000-0003-0927-7498

Attf: Yeşildal, A. (2020). Yerel yönetimlerin yoksullukla mücadeledeki yeri: Küresel düzeyden yerel düzeye yeni yönelimler. Sosyal Siyaset Konferansları Dergisi, 78: 455-481. https://doi.org/10.26650/jspc.2020.78.0027 


\begin{abstract}
The United Nations Development Program (UNDP) estimates that around one billion people worldwide live under conditions of extreme poverty with under one dollar per day, cannot meet their basic human needs, and that at least one billion people live in relative poverty. This means more than one third of the world's children are malnourished, more than 840 million adults, including more than half women, are illiterate and 1.2 million live without access to safe drinking water. This painful picture of global poverty clearly demonstrates that poverty has become a more chronic problem than ever before. Due to this situation, local governments have become more involved in the struggle against poverty recently. As a matter of fact, for various reasons, local governments can take an active role in the fight against poverty. However, local governments often lack data and information to identify causes of poverty, prioritize interventions, or target specific groups of the poor. Previously ignored by central planning, local governments have had little experience in the preparation and implementation of development plans. Inadequate delegation of power, disproportionate allocation of resources, or poor coordination between sectors further limited the capacity of local authorities to meet local needs. Limited downward accountability also limited the action of the political will of the newly authorized authorities. In short, local governments and local interventions have not been able to gain the deserved place and power in effective anti-poverty policies for a long time, but where they can play a more effective role in contemporary anti-poverty policies all over the world.
\end{abstract}

\title{
Keywords
}

Poverty, Poverty alleviation, Local government, Globalisation, Localisation 


\section{Extended Summary}

One of the oldest social policy problems of all times, poverty has direct impacts on many aspects of human living conditions through physical, moral, and psychological outcomes. Therefore, countless numbers of criteria and approaches have been developed to conceptualise poverty so far. While many of them analyses the traditional aspects of poverty in the form of insufficient and irregular income to secure basic needs, others partly examine poverty in its intangible dimensions, such as education, health, life expectancy, child mortality etc.

The problem of identifying and measuring poverty is extremely complex due to the different factors that contribute to the problem. Thus, the problem requires more than economic growth. There are still a significant number of people struggling to survive even in the developed countries with strong economies. Understanding well-being and poverty is the first step to reduce poverty. Meaningful definitions are important to determine the causes of poverty and poverty reduction goals as well as the scope of what needs to be done. Local governments need the concepts of welfare and poverty to help them make the right decisions at the local level. These concepts can be a starting point for central and local governments to better understand the relationship between poverty and welfare.

However, if the necessary coordination and harmony between local governments and central government cannot be achieved in combating poverty, it is inevitable that there will be repeated interventions. This will lead to the inability to use the resources which are very precious and limited, as well as to prevent individuals from getting out of poverty. Therefore, the ability of local governments to fully fulfil the roles expected from them in the fight against poverty depends primarily on their work in a compliant and complementary manner with the central government.

Local governments also have some natural obstacles to tackle poverty. As a matter of fact, they often face problems such as determining the causes of poverty, prioritizing those interventions among other obligations, or lacking data and information that primarily target certain poor groups. Local governments, which have not been given sufficient roles with central planning before, naturally have little experience in the preparation and implementation of local development plans. Other problems and obstacles such as insufficient 
delegation, insufficient and disproportionate resources, and poor coordination among sectors have further restricted local governments' capacity to meet local needs. Nevertheless, since poverty is a problem that needs to be eliminated completely, local governments have important contributions to this issue.

Poverty occupies the socioeconomic policy agenda of governments all over the world. Collaborations between partners, participatory processes, and local stakeholders are key features of the new initiatives reviewed. One of the most common trends in tackling poverty at the local level is the development of new programs to improve the level of living of poor individuals clustered in slum areas. These programs are much more than traditional direct cash supports. They are more suitably called social inclusion policies. As a matter of fact, it is now clear that poverty is not only a lack of material income, but rather a decrease in the welfare levels and rights of individuals.

Another precise point is that central governments cannot fight poverty by themselves anymore. Therefore, it is a definite necessity for a large number of actors, such as central-local governments, the private sector, supranational organizations, and non-governmental organizations, to combat and struggle against poverty altogether. However, such partnerships are vulnerable. When the interests of one of the partners change, the entire partnership can be resolved and excellent initiatives deprived of political support and resources may collapse. The most common cause of conflict among partners is political privileges and preferences. Excessive politicization of problems and cuts in leadership can lead to disruptions. Election strategies, political maneuvers, and personal conflicts within local authorities and partner organizations may result in partial or complete separation.

In studies related to poverty and local governments, it appears that the local government capacity is an important determinant of the level of effectiveness in poverty prevention. This supports the latest local economic development literature, which argues that local governments have some degree of control over local resources that can override the effects of poverty and other structural inequalities. Therefore, it is a definite necessity to support and increase the autonomy levels of local governments in the fight against poverty in many ways, especially the sharing of authority. 


\section{Yerel Yönetimlerin Yoksullukla Mücadeledeki Yeri: Küresel Düzeyden Yerel Düzeye Yeni Yönelimler}

Yeryüzünün en eski sosyal politika sorunlardan biri olan yoksulluk fiziksel, ahlaki ve psikolojik boyutlar da dâhil olmak üzere beşeri yaşam koşullarının birçok yönünü etkilemektedir. Bu nedenle, günümüze gelene kadar yoksulluğu kavramsallaştırmak için sayısız kıstaslar ve yaklaşımlar geliştirilmiştir. Çoğu analiz, temel mal ve hizmetlerin güvence altına alınması için yeterli gelir elde edilmemesi şeklinde yoksulluğun geleneksel görünümünü dikkate alırken, diğerleri ise kısmen yoksulluğu, eğitim, sağlık, yaşam beklentisi, çocuk ölümleri gibi maddi olmayan boyutlarıyla incelemektedir.

Benzer bir durum, yoksullukla mücadele politikalarında ülkelerin benimsediği tercihlerde de görülmektedir. Bu kapsamda, yoksullukla mücadelede yerel yönetimler çeşitli platformlarda gittikçe daha fazla gündeme gelmektedir. Artık yoksullukla sadece merkezi yönetimler marifetiyle mücadele edilmemektedir. Yerel yönetimlerin yoksullukla mücadelede gereken esnekliği sağlamanın yanında, hızlı müdahale etme, sorunun kökenini daha yakından teşhis edebilme ve farklı ihtiyaçlara farklı programlarla cevap verebilme gibi birçok üstünlüğü bulunmaktadır.

Bununla birlikte, yoksullukla mücadelede yerel yönetimlerle merkezi yönetim arasında gereken eşgüdümün ve uyumun sağlanamaması halinde, mükerrer müdahalelerin olması da kaçınılmazdır. Bu da çok kıymetli ve bir o kadar da kısıtlı olan kaynakların verimli kullanılamamasına, bireylerin yoksulluk kıskacından kurtulamamasına yol açacaktır. Dolayısıyla, yerel yönetimlerin yoksullukla mücadelede kendilerinden beklenen rolleri tam anlamıla yerine getirebilmeleri en başta merkezi yönetimle uyumlu ve birbirini tamamlayan bir biçimde çalışmalarına bağlıdır.

Yerel yönetimlerin yoksullukla mücadele konusunda bazı doğal engelleri de vardır. Nitekim genellikle, yoksulluk nedenlerini belirlemek, diğer yükümlülükleri arasında bu müdahalelere öncelik vermek veya belli yoksul gruplarını öncelikle hedef alan veri ve bilgilerden yoksun olmak gibi sorunlarla karşı karşıyadırlar. Daha önce merkezi planlama ile yeterince önem verilmeyen yerel yönetimler, yerel kalkınma planlarının hazırlanması ve uygulanmasında doğal olarak çok az deneyime sahiptir. Yetersiz yetki devri, kaynakların yetersiz ve orantısız olması, sektörler arasında koordinasyonun zayıf olması 
gibi diğer sorun ve engeller yerel yönetimlerin yerel ihtiyaçları karşılama kapasitelerini daha da kısıtlamıştır. Ancak her şeye rağmen, yoksulluk topyekûn müdahale edilmesi gereken bir sorun olduğu için yerel yönetimlerin bu konuda sunabilecekleri son derece önemli katkılar bulunmaktadır.

Esas olarak yerel yönetimlerin yoksullukla mücadeledeki önemini ortaya koymayı hedefleyen bu çalışma, son y1llarda yerel yönetimlere atfedilen rol ve sorumlulukların arttı̆̆ gerçeğinden hareket etmektedir. Bu kapsamda, çalışmanın temel meselesi olan yoksulluğa ilişkin geleneksel ve çağdaş bakış açılarının birlikte sunulduğu bir kavramsal çerçeveyle başlanılmış, ardından küreselleşmeyle birlikte yoksulluk olgusunda meydana gelen değişikliklere değinilmiş ve yeni dönemde tüm bu etkiler 1şığında yerel yönetimlerin yoksullukla mücadele kapsamında üstlendikleri roller tartışılmıştır. Çalışmanın en sonunda ise konuya ilişkin sonuç tartışmasına yer verilmiş̧tir.

\section{Yoksulluk Olgusuna İlişkin Kavramsal Tartışma}

Yoksulluk, düşük refah düzeyini yansıtan karmaşık ve çok boyutlu bir kavramdır. İktisatçılar gelir ya da harcama akışlarını refah için bir koşul olarak kullanma eğilimindedirler. Bu yaklaşım sosyal bilimlerde uzun bir süredir tartışılmaktadır ve çok boyutlu yoksulluk tedbirlerinin kullanımında kayda değer bir ilerleme sağlamıştır (Barrett, 2005, s. 45). Yoksulluk kavramını tanımlamak, akademideki en sorunlu alanlardan biridir. Çok boyutlu bir olgu olarak yoksulluğun evrensel kabul görmüş bir tanımı yoktur. Örneğin, Dünya Bankası Kalkınma Raporu (1990), bir hanehalkının veya bireyin, fiziksel ve sosyal varlığını sürdürebilmesi için gerekli görülen mal ve hizmetleri satın almak için ihtiyaç duyduğu gelirleri ifade eder ve yılda 370 ABD doları (veya günde $1 \mathrm{ABD}$ doları) şeklinde bir düzey öngörür. Bu düzey, gelişmekte olan ülkelerde mutlak yoksulluk sınırı için bir ölçü kabul edilir. Bu ölçüye göre, gelişmekte olan dünyadaki nüfusun yaklaşık yüzde 33'ünün yoksul olduğu kabul edilmektedir (Ameyaw ve Bawole, 2009, s. 492). Ancak Dünya Bankasının kullandığı bu yöntemin farklı gruplardan ve bireylerden hem destek hem de eleştiri alarak, yoğun bir tartışma ortamı yarattığını belirtmek yerinde olacaktır. Bununla birlikte, birçok uzman yoksulluğu "temel tüketim ihtiyaçları üzerinde bir erişim eksikliği” olarak görmektedir. Bu da yetersiz yiyecek, giyecek veya barınmaya neden olan yetersiz tüketim düzeyinin yanı sıra, toplumda insan onuruna yaraşır bir yaşam sürdürememeyi içermektedir. 
Genyi (2008, s. 10) bu konuda şu fikirleri ileri sürmüştür:

Yoksulluk, sürdürülebilir geçim kaynakları, açlık ve yetersiz beslenme, kötü sağlık, sınırlı veya eğitim ve diğer temel hizmetlere erişimin olmamasl, hastalıktan kaynaklanan hastalıkların artmasını sağlamak için yeterli gelir ve üretkenlik kaynaklarının eksikliği gibi çeşitli tezahürlere sahiptir. Sosyal ayrımcılık ve dışlanma, aynı zamanda karar alım süreçlerinde ve sivil, sosyal ve kültürel hayatta katılım eksikliğidir.

Kısaca özetlemek gerekirse, yoksulluk sadece geleneksel anlamdaki yiyecek, giyecek ve barınma gibi temel ihtiyaçları karşılayacak kadar paraya sahip olmamakla ilgili değildir. Bunların çok daha fazlasını ifade etmektedir.

Para eksikliğine ek olarak, yoksulluk, rekreasyonel faaliyetlere katılamamayla ilgilidir. Çocukları okul gezilerine veya bir doğum günü partisine, bir günlük seyahate gönderememek, bir hastalık için ilaç parasını ödeyememek gibi eksilikleri de kapsar. Bunların hepsi yoksul olmanın maliyetidir (Domfeh ve Bawole, 2009, s. 492). Mutlak yoksulluk, gelir ve maddi kaynaklara erişim temelinde sabit bir eşik anlamına gelirken, göreceli eşitsizlik, bir bölgenin medyan geliri ve yaşam standardı kullanılarak ölçülür ve dolayısıyla gelir eşitsizliğini yansıtır. Göreceli yoksulluk, yoksulluğun sosyal olarak tanımlanmış ve sosyal içeriğe bağlı olduğunu açıklar. Genel olarak, göreceli yoksulluk, geliri belli bir medyan gelirden daha az olan nüfusun yüzdesi olarak ölçülür.

Yoksulluk kavramı genellikle yoksunluk, gelişme eksikliği, kıtlık, geri kalmışlık, refah eksikliği, güçsüzlük, yaşam kalitesinin düşüklüğü, insanın ıstırabı vb. ile ilgilidir. Yoksulluk tanımları ve algıları çok çeşitli ve belirsizdir (Dixon ve Macarov, 2002, s. 14). Tanımların çeşitliliğinin yanı sıra, kesin olan bir başka konu, yoksulluğun karmaşık bir toplumsal mesele olduğudur. Yoksulluk ne kadar farklı tanımlanırsa tanımlansın, toplumun tüm kesimlerinin dikkatini gerektiren bir konu olduğu kabul edilebilir. Bu açıdan toplumun tüm üyelerinin, potansiyellerine tam olarak ulaşmalarını sağlamak için birlikte çalışması önemlidir.

\section{Yoksulluğun Çeşitleri}

Yoksulluk, küresel medeniyetle yüzleşmenin kilit zorluklarından biri olarak uzun bir süredir devam etmektedir ve muhtemelen devam da edecektir. Yoksulluk her yerde görülebilir, ancak bunun şekli ve doğası bölgeden bölgeye ve ülkeden ülkeye değişebilir. Yoksulluğun düzeltilmesinin 
toplumsal gelişim için temel bir gereklilik olmasına rağmen, dünyada 420 milyon civarında kronik yoksul insan bulunmaktadır (Bradshaw, 2006, s. 9). Yoksulluk, genellikle "mutlak" yoksulluk (bir insanın fiziksel varlığını garanti altına almak için minimum gerekli gelirden yoksun olması), "göreceli" yoksulluk (belirli bir yaşantının ortalama yaşam standardının gerisinde olması) gibi kavramsallaştırmalarla kapsam ve nitelik bakımından tanımlanır (Bonfiglioli, 2003, s. 18).

Yoksul birey sadece kaynak eksikliğine sahip olan birey değil, yaşam standardını iyileştirme ve yeni kaynak edinme fursatlarından da yoksun olan bireydir. "Yaşam şansı", bir kişinin kaynaklara erişimini tanımlamak için kullanılan bir terimdir. Yoksulluk içinde yaşayan ancak yüksek yaşam şansına sahip olan biri ekonomik durumunu iyileştirebilir, ancak düşük yaşam şansına sahip biri muhtemelen düşük bir yaşam standardına sahip olacaktır. Bu yoksulluk eşiği gelecek için korkuyla başlar ve bağımlılık, bask1 ve hatta sömürüyü içerecek şekilde genişler. Bu daha büyük yoksulluk ölçüsü, yoksulluğun katkılarını ve nedenlerini genişlettiğinden, Dünya Bankası yoksulluğun gelir dışı boyutlarını değerlendirmek için göstergeler geliştirmiştir. Göstergeler eğitim, sağlık, sosyal hizmetlere erişim, sosyal güvenlik açığı, sosyal dışlanma ve sosyal sermayeye erişimi içerir.

Mutlak yoksulluk tanımının en temel özelliği, yoksulluğun kesinlikle ekonomik anlamda ölçülmesine dayanmasıdır. Mutlak yoksulluk gelir düzeyinin, mülk sahipliğinin ve diğer kaynakların az olduğu ya da hiç olmadığı bir durum olarak görülmektedir. İlk ölçüt, açlık sınırına yakın kişileri veya maruz kalmaktan dolayı ölümleri içerecektir. İkinci ölçüt ise beslenecek insanlara uzanacaktır. Mutlak yoksul, yaşamın temel gerekliliklerini sağlamada yetersiz kalırken, göreceli yoksul, bir bireyin veya bölgenin mutlak yoksullukta diğerlerinden daha fazla görünür olduğu bir durumdur (Ashaver, 2013, s. 36).

Yukarıdaki duruma uygun olarak, mutlak yoksulluğun düşük kalori alımı, yetersiz konut, yetersiz sağlık tesisleri, eğitim tesislerinin kalitesinin düşük olması, düşük yaşam beklentisi, yüksek bebek ölüm oran1, düşük gelir, işsizlik ve az gelişmişlik ile karakterize olduğu ileri sürülmektedir. Mutlak yoksul bireyler temel ihtiyaçlarını karşılayamazlar. Diğer bir deyişle yoksulluğun, iyi bir yaşam tarzını sürdürmek için gerekli olan temel tercihlerin ve firsatların yoksunluk ya da reddedilme durumu olduğunu açıkça göstermektedir(Ashaver, 2013, s. 35). Dolayısıyla mutlak yoksulluk düzenli yiyecek ve barınak sahibi 
olamamak gibi hayatta kalmaya ilişkin temel ihtiyaçlardan yoksun olma anlamına gelirken, "göreli yoksulluk" toplumun varlıklı üyelerine kıyasla ekonomik dezavantaj sahibi olma anlamına gelmektedir (Olowa, 2012, 28).

\section{Yoksulluğun Ölçülmesi}

Yoksulluk herkes için aynı değildir. Bir kişi günde 3 dolar kazanıyor olabilir, ancak finansal kapasitesinin hala nüfusun geri kalanıyla karşılaştırılması gerekir. Öyleyse, ABD'deki yoksul bir insan, Sahraaltı Afrika'daki yoksul bir insandan farklı bir yoksulluk seviyesine sahiptir. Dünya Bankası'nın rakamlarına göre, dünya nüfusunun ve tüm çocukların neredeyse yarısı üzere günde 2 dolardan az bir gelirle yaşamaktadır. 2018 yılında bu rakam bir milyarın altına düşmüş olsa da yoksulluğun istatistiksel ölçümü son derece tartışmalıdır. En azından günde bir dolarlık önlemler gelişmekte olan ülkelerin yükselen gecekondu mahallelerinde yaşamanın acımasız gerçekliğini yansıtmamaktadır. Diğer bir kitleye göre, milyarlarca yoksul insanın yaşam kalitesi bozulmaya devam etmektedir. Bu durum küreselleşmenin büyük bir kesim için gittikçe daha fazla yıkıcı hale geleceği ve vaat edilen refahı sağlayamayacağının bir göstergesi olarak ifade edilmektedir.

Yoksulluğun ölçülmesine ilişkin temel aşamalar, yoksulluğun tanımlanması ile yoksulluk kıstaslarının ölçüm sorun ve yöntemlerinin belirlenmesinden oluşmaktadır (Şenses,2001, s. 61). Yoksulluğun ölçülmesi önemli bir teknik mesele olmasına rağmen, buradaki odak nokta, yoksulluk sınırının nerede olduğu veya tam olarak ne kadar insanın bu sınırın ne kadar altına düştüğü ya da belirli bir zamanda ne kadar altına düşeceğidir. Bunlar tartışmasız önemli konular olmasına rağmen, doğal olarak statik kaygılardır. Aksine, buradaki odak nokta, refah ölçütlerinin dinamikleri üzerinden belirlenen bir yoksulluk sınırına bağlı olarak daha dinamik bir yoksulluk yaklaşımı geliştirme kaygısıdır (Barrett,2005, s. 48). Öte yandan, yoksulluğun ölçülmesinde ve analiz edilmesinde büyük ilerleme kaydedilmesine rağmen, Dünya Bankası yoksulluğun diğer boyutlarına ilişkin göstergeleri belirlemek için daha fazla çalışma yapmaktadır (Uzun, 2003, s. 156). Bu çalışmalar esas olarak eğitimi, sağlığı, hizmetlere erişimi, sosyoekonomik kırılganlığı ve sosyal dışlanmayı izlemek için sosyal göstergeleri tanımlamayı içermektedir.

Yoksulluk yapısal (kronik) veya geçici olabilir. Yapısal ya da kronik yoksulluk, kalıcı sosyoekonomik yoksunluklar olarak tanımlanmaktadır ve sınırlı üretken 
kaynaklar, kazanç getirici düzenli istihdam için gereken beceri eksikliği, endemik sosyo-politikvekültürelfaktörlervecinsiyetgibibirdizifaktörlebağlantılıdır. Geçici yoksulluk ise doğal ve insan yapımı felaketlerle bağlantılıdır. Geçici yoksulluk daha geri dönüşümlü ve giderilebilirdir; ancak devam ederse yapısal hale gelebilir (Olowa,2012, 26). Yoksulluğun ekonomik ölçütleri, genellikle yiyecek, giyecek, barınak veya güvenli içme suyu gibi günlük yaşam gereksinimlerini de içerecek şekilde, maddi ihtiyaçlara odaklanır. Bu anlamda yoksulluk, bir kişinin veya toplumun, özellikle kalıcı bir gelir eksikliğinden dolayı asgari bir refah standardı için temel ihtiyaçlardan yoksun olduğu bir durum olarak anlaşılabilir.

Yoksulluğun sosyalölçütleri, bilgiye, eğitime, sağlık hizmetlerine veya politik güce erişim eksikliğini içerebilir. Yoksulluk, sosyal dışlanma, bağımlılık ve/ veya topluma katılma kapasitesinin azalması gibi deneyimlenen, eşitsiz sosyal ilişkilerin bir yönü olarak da anlaş1labilir (Olowa,2012, s. 26). Dünya Bankasına göre yoksulluğun tanımları düşük gelirli ve onurlu yaşamak için gerekli temel mal ve hizmetlerin elde edilememesini içermektedir. Yoksulluk aynı zamanda düşük sağlık ve eğitim seviyelerini, temiz su ve sağlık hizmetlerine erişimi, yetersiz fiziksel güvenliği, sesini duyurabilme eksikliğini, yetersiz kapasiteyi ve kişinin yaşamını daha iyi hale getirme fırsatlarını da kapsamaktadır.

Hemtanımlanmasıhem deölçülmesizorbirolgu olarakyoksulluk, başvurulan kavramlardaki çeşitliliğe, veri sınırlamalarına ve farklı metodolojilere bağlı olarak hemen her dönemde en fazla tartışılan sosyal politika meselelerinden biri olmuştur ve olmaya da devam edecektir. Yoksulluk, gelir ve diğer finansal kaynaklara erişim gibi bir dizi maddi faktörden etkilenen bireysel yaşam standartlarıyla ve aynı zamanda büyük ölçüde tahmin edilemeyen ancak bir kişinin genel standardını etkileyebilecek olan toplumsal ve aile bağları gibi maddi olmayan faktörlerle de ilgilidir. Bu olgusal genişliğin getirdiği sınırlamalara rağmen, yoksulluk araştırması ve yoksulluk önlemlerinin geliştirilmesi, toplumdaki yoksulluğun doğasının ve kapsamının ve uygun politika yanıtlarının geliştirilmesinde önemlidir.

\section{Küreselleşme ve Yoksulluk}

Küreselleşmenin özellikle gelişmekte olan ülkelerin yoksulluk seviyeleri üzerindeki etkileri hem uluslararası örgütler hem de bu örgütlerin başta gelen finansman sağlayıcıları için kilit bir endişe kaynağıdır (Stiglitz,2018, s. 8-9). Bu yüzden küreselleşme-yoksulluk ilişkisi çok yönlü kanalları içeren 
karmaşık ve heterojen bir ilişki olarak kabul edilmektedir. Küreselleşmeyoksulluk ilişkisinin, birçok eşik etkisinin olduğu ve çeşitli yönlerden doğrusal olamama ihtimali bulunduğu oldukça kuvvetli bir ihtimal olarak karşımıza çıkmaktadır. Küreselleşmenin yoksulluk üzerindeki etkilerini evrensel olarak gözlemlenebilir koşullar şeklinde teorize etme çabaları sonuç vermeyebilir. Nitekim küreselleşme - büyüme-gelir dağılımı - yoksulluk bağının içine gömülmüş olan her bir alt bağlantı seti tartışmalı olabilir. Küreselleşmenin yoksulluk üzerindeki "büyüme" etkilerinin yanı sıra (yani küreselleşmenin doğrudan ekonomik büyüme yoluyla filtrelenen yoksulluk üzerindeki etkileri), başka kanallar vasıtasıyla sürecin kazananlarını ve kaybedenlerini de aynı anda yarattığı bilinmektedir. Bu kanallar arasında göreceli faktör ve fiyat değişiklikleri, teknolojik değişimin ve yayılmanın doğası, küreselleşmenin kırılganlık üzerindeki etkisi, dünya çapında bilgi akışı ve küresel enflasyondaki düşüş en başta sayılabilecek olanlardır (Nissanke ve Thorbecke, 2000, s. 1342).

Küreselleşme aynı zamanda son derece politik bir olgudur. Ulusötesi sermaye kurumları ulus devletler ve gittikçe birbirine bağımlı bir dünyada tutarlılık ve düzen getirmekle görevli uluslararası kurumlar arasındaki karmaşık müzakereler ve etkileşimlerle şekillenir. Ekonomi, çokuluslu şirketler, hükümetler, Birleşmiş Milletler Örgütleri, Dünya Ticaret Örgütü veya Dünya Bankası ve Uluslararası Para Fonu gibi uluslararası finansal kurumlar bireysel ve kolektif aktörlerin eylemleri ve seçimlerinin dışında bir hareket alanına sahip değildir (Guttal, 2007, s. 526).

Ekonomik küreselleşme, son yıllarda dünya ekonomisini karakterize eden uluslararası ticaret ve sermaye akımlarının önemli ölçüde genişlemesi anlamına gelmektedir. Hemen hemen her ülkede, insanlar giderek daha fazla mal ithal etmekte ve uluslararası operasyonları olan şirketler adına çalışmaktadır. Sonuç olarak, ekonomik küreselleşme yalnızca insanlara sunulan mal ve hizmet çeşitlerini değil, aynı zamanda işleri, gelirleri ve firsatları da etkilemiştir (Rassekh ve Speir, 2010, s. 30).

Son y1llarda küresel yoksulluk sorunuyla mücadelede önemli gelişmeler olduğunu gösteren eğilimler de vardır. Göreceli olarak, 1990 ve 2015 yılları arasındaki aşırı yoksulluğu yarıya indirmek şeklindeki temel Binyıl Kalkınma Hedefine ulaşılmıştır. Gelişmekte olan bölgelerde, aşırı yoksulluktaki insanlar nüfusun yüzde 14'ünü oluştururken, en son rakamlar ve tahminler hala iki milyardan fazla insanın günde ortalama 2 doların altında yaşadığını ve 
yoksulluğu ölçmek için kullanılan bir kıstas olduğunu göstermektedir (World Bank, 2018, s. 14).

- En son tahminlere göre, 1990 yılında dünya nüfusunun yaklaşık yüzde 36's1, 2013 yılında ise yüzde 11'i yoksulluk sınırının altında yaşamakta iken 2015 yılında yüzde 10'dan daha az bir kesimi günde 1.90 \$ ile yaşamını sürdürmüştür.

- 1990 yılında 1,1 milyar insan aşırı yoksulluk içinde yaşıyorken, 2015 yılında 736 milyon insan günde 1,90 doların altında yaşamını sürdürmüştür.

- Yoksulluk oranları tüm bölgelerde düşmekle birlikte ilerleme düzensizdir:

- İki bölge, yani Doğu Asya ve Pasifik (47 milyon aşırı yoksul) ile Avrupa ve Orta Asya (7 milyon), aşırı yoksulluğu 2030 hedefine ulaştırarak yüzde 3'ün altına düşürmüştür.

- Aşırı yoksulların yarısından fazlası Sahraaltı Afrika'da yaşamaktadır. Aslında, bölgedeki yoksulların sayısı 9 milyon artarken, 413 milyon insan 2015 y1lında günde 1.90 dolardan az bir gelirle yaşamak zorunda kalmıştır. Eğer eğilim devam ederse 2030 yılında, her 10 aşırı yoksuldan yaklaşık 9'u Sahraaltı Afrika'da yaşayacaktır.

- Küresel yoksulların çoğunluğu kırsal alanlarda yaşamakta, zayıf eğitim görmekte, tarım sektöründe çalışmakta ve 18 yaşın altında bulunmaktadır (World Bank, 2018, s. 14).

Aşırı yoksulluğu sona erdirme işi bitmediği gibi birçok zorluk da devam etmektedir. En son tahminler, dünyanın 2030 yılına kadar aşırı yoksulluğu ortadan kaldıramayacağı göstermektedir. Bunun nedeni, aşırı yoksulluk içinde yaşayanlara ulaşmadaki zorluktur. $\mathrm{Bu}$ yüzden milyonlarca insan için iyi okullara, sağlık hizmetlerine, elektriğe, temiz suya ve diğer kritik hizmetlere erişim, çoğu zaman sosyoekonomik durum, cinsiyet, etnik köken ve coğrafyadan dolayı belirsizdir. Üstelik yoksulluktan kurtulabilenler için ilerleme genellikle zordur: Ekonomik krizler, gıda güvensizliği ve iklim değişikliği yoksulluktan kesin kurtuluşu tehdit etmektedir (World Bank, 2018, s. 10). 
Torado ve Smith'in de (2006) belirttiği gibi, XXI. yüzyılın en önemli sorunu yoksulluğun ortadan kaldırılmasıdır ve bu konuya uluslararası toplum, hükümetler ve yardım kuruluşları daha önce benzeri görülmemiş bir ilgi göstermeye devam edecektir (Todaro ve Smith, 2006, s. 22). Bu yüzden birçok kurum yoksulluğun azaltılmasına öncelik veren politika belgeleri hazırlamıştır. Ulusal düzeyde, birçok ülke yoksullukla mücadelede bağışçı desteğini talep etmek için hazırlanan planlar kapsamında Yoksulluğu Azaltma Strateji Belgeleri (PRSP'ler) geliştirmiştir. Bu belgeler uluslararası düzeyde, hükümetlerin ve yardım kuruluşlarının yoksulluğun ortadan kaldırılması nihai hedefine doğru ilerlemeyi ölçebilecekleri küresel hedefler sunmaktadır Binyıl Kalkınma Hedefleri öz itibariyle, 2015 yılına kadar yoksulluk içinde yaşayan insanların azaltılması ihtiyacını vurgulamaktadır. Açıkça anlaşılacağı üzere, neoliberal politikalara dayalı reformlar daha yüksek ekonomik dengesizliğe yol açmaktadır (CPRC, 2004). Bu nedenle, sorunla mücadelede çok daha yeni ve radikal tedbirlerin geliştirilmesi gerekmektedir.

\section{Yerel Yönetimlerin Yoksullukla Mücadele Etmesinin Nedenleri}

Yoksulluk ile yerel yönetim faaliyeti arasındaki ilişki, âdem-i merkeziyetçi yönetim anlayışının geliştiği günümüzde önemli bir hale gelmiştir. Yerel yönetimler yoksulluğun yerelleşmesi neticesinde kentsel yoksulluk kavramıyla tanışmıştır. Yerel yönetimler ülke genelinde yoksulluk konusuyla yakından ilgilenmektedir. Bunun birinci nedeni, belediyelerin ilçe, büyükşehir ve metropol olmayan daha küçük ve merkezden fark edilmesi çok daha güç bölgeleri kapsamasıdır. İkincisi ise kırsal kesimlerin tarihsel olarak daha yüksek yoksulluk oranlarına sahip olmasıdır. Kentlerde yaşayan yeni yoksullarla birlikte yerel yönetimler konuyla yakından ilgilenmek zorunda kalmış ve kentsel yoksullukla mücadelede yerel yönetimler zamanla temel araç haline gelmiştir (Batal, 2016, s. 309).

Yoksulluk kavramının yerelleşmesi son elli yıla dayanan kentlere yönelik yaşanan yoğun göç hareketleri neticesinde ortaya çıkmıştır (Batal, 2016, s. 302). Özellikle yerel yönetimler, yoksullukla mücadele konusunda muazzam bir potansiyele sahiptir. Ancak önceliklerini belirlemek, stratejileri tanımlamak ve ardından harekete geçmek başarılı olmak için bir zorunluktur. Son yirmi yılda birçok ülkede, yoksullukla mücadele konusunda yerel yönetimlere bir hayli yetki verilmiştir. Ülke çapında yerelleşmeye yönelişin bir parçası 
olarak, yerel yönetimler ekonomik kalkınmada, sosyal hizmetlerin ve kamu hizmetlerinin sağlanmasında gittikçe daha fazla sorumluluk üstlenmektedirler (Lobao ve Kraybill, 2009, s. 423).

Yoksullukla mücadelede hizmet sunum standartlarını, normlarını ve yerel yönetimlerin yerel altyapı çalışmalarını planlamalarına, tasarlamalarına ve uygulamalarına yardımcı olmak için uygun kuralların geliştirilmesinde önemli çaba sarf edilmiştir. Bununla birlikte, yerel kaynak bazlı çalışmaların getirilmesi ek teknik bilgi birikimi de gerektirmektedir (ILO, 2018, s. 7).

Yerel yönetimler, merkezi yönetime göre dinamik ve girişimci bir yapıya sahiplerdir (Batal, 2016, s. 308). Yerel bir hükümetin yoksullukla mücadeleye yönelik kapsamı, âdemi merkeziyetçilik politikaları, mevcut kaynakları ve bu kaynakları kullanmak için aldığ 1 kararların sağladığı yasal çerçeve ile şekillenir. $\mathrm{Bu}$ açıdan yoksulluğa neden olan faktörlerin, eylemler için bir strateji belirleme konusunda yerel yönetimlerden gerçekten etkilenip etkilenmediğini belirlemek önemlidir.

Yerel yönetimlerin yoksulluğun önlenmesinde atabilecekleri dört adım vardir:

- Yerel kesimdeki yoksulluğu anlamak

- Yoksullarla iletişim kurmak ve koordine etmek

- Yoksullara yarar sağlayacak eylemlerde bulunmak

- Refahın farklı yönleri arasında bir denge kurmak

\section{Yerel Kesimdeki Yoksulluğu Anlamak}

Yerel yönetimler kendi bölgelerinde yoksulluğun niteliğini anlamak için aşağıdaki soruları cevaplamaya ihtiyaç duymaktadır:

- Kimler yoksuldur ve nerede toplanmışlardır?

- Bölgedeki hakim yoksulluk tipinin özellikleri nelerdir?

- Yoksulluğun algılanmasındaki yerel farklılıklar nelerdir?

- Yoksulluğun sebepleri ve koşulları nelerdir? 
- Yoksulların farklı gruplarının öncelikleri nelerdir?

- Yoksulların şu andaki geçim kaynakları veya başa çıkma stratejileri nelerdir?

- Bölge genelindeki yoksulluğu azaltma çabaları ne kadar iyi çalışıyor?

Yoksulluğu anlamak, yoksulları ve kalkınma faaliyetlerinin onlara nasıl yardımcı olabileceğini öğrenmeyi gerektirir. Aynı zamanda, yoksulluk koşullarının nasıl değiştiğini anlamak demektir. Yerel yönetimlerin anlayışlarını güncel tutmak için bu soruların zaman zaman ele alınması gerekir. Yoksul haneler genellikle riskleri dengelemek için çeşitli geçim kaynakları bulmakta ve sürdürmekte ustadır. Bu nedenle, kalkınma müdahaleleri bu bireylerin hayatta kalma stratejilerini baltalamama ve onları dış yardım ve desteklere bağımlı bireylere dönüştürmemeye özen göstermelidir. Yoksulluk hakkında bilgi toplamak genel ve sürekli bir izleme ve değerlendirme programının bir parçası olabilir (Carter,2006, s. 180).

\section{Yoksullarla İletişim Kurmak ve Koordine Etmek}

Yerel yönetimlerin yoksullukla mücadele konusunda karşılaştıkları en büyük zorluklardan biri, yoksullarla iletişim, etkileşim ve eşgüdüm sağlamaktır. Birçok yerde, yoksullar, yerel politikada çok az etki sahibidir, erişilemeyen bölgelerde yaşamaktadır veya etnik köken, sınıf veya cinsiyet temelinde önyargı ve ayrımcılığa maruz kalmaktadır. Ancak, yoksulların yeteneklerini geliştirmek ve daha sonra ekonomik ve politik kazanımlar elde etmek için güçlü bir temel oluşturulabilir. İletişimin ve eşgüdümün iyileştirilmesi, yerel yönetimlerin ve yoksulların birlikte harekete geçmek için karşılıklı anlayışı ve yapıcı katılımı geliştirmelerine yardımcı olabilir.

Yerel yönetimler yoksul insanların önceliklerini daha iyi anlamak için onlarla doğrudan temaslarını açık tartışmalar şeklinde tekrar tekrar yapmalıdır. İyi iletişim neredeyse zorunlu olarak, yoksulları evlerinde ve tarlalarında ziyaret etme taahhüdü gerektirir. İnsanlar görüşlerini ifade etmeye kendi ortamlarında bir devlet dairesinden daha istekli olabilirler. Yoksulların günlük yaşamlarını sürdürdüğü yerlerdeki fiziksel varlık, yetkililerin, yoksulların yaşadıklarına ilk elden şahit olmalarına yardımcı olur.

Yoksulların farklı gruplarının katılımını ve temsilini güçlendirmeye 
yönelik tedbirler ve onlara karşı hesap verebilirlik, devletin karar vermesinde yoksulların görüşlerini desteklemek için gereklidir. Bu tür önlemlere örnek olarak, toplantıları yoksullar için daha erişilebilir yerlerde yürütmek, kararlarda pay sahibi olmalarını sağlamak veya insanların fikirlerini dile getirmeye davet edildiklerini bildirmek gibi basit eylemler bile sayllabilir. Yerel yönetimler daha sonra alınacak önlemleri geliştirmek için yoksullarla birlikte daha iyi çalışabilir (Carter ve Barrett, 2006, s. 180).

Kadınların, çocukların, yaşlıların ve özellikle göz ardı edilip marjinalize edilme riski altında olan bazı etnik grupların ihtiyaçlarını ele almak için büyük çaba gösterilmelidir. Aynı zamanda, dezavantajı kişilerin damgalanmamasına veya güçsüzleştirilmemesine dikkat edilmelidir. Aksi takdirde bu durum onları daimi olarak "yoksul" bir kategoriye sokar. Buna karş1lık, yoksulluğun azaltılması müdahaleleri, bir grubun diğerine, örneğin erkeklerin kadınlara ya da diğer gruplara göre bir üstünlük politikası olarak algılanıyorsa, yoksul alt gruplar arasında olumsuz dinamikleri tetikleyebilir.

\section{Yoksullara Fayda Sağlayacak Eylemlerde Bulunmak}

Yerel yönetimler verdikleri kararlarla yoksulluğu etkileyebilir. Yoksullara daha duyarlı olma firsatları, her yıl planlama ve bütçe tahsis sürecinde ve kararların nasıl uygulandığına bağlı olarak ortaya çıkmaktadır. Fırsatlar da beklenmedik şekilde ortaya çıkabilir. Yerel yönetimler düzenli bilgi topluyorsa ve seçmenlerini dinliyorsa, yapılması gereken eylemlerin daha fazla farkında olacaklardır. Etkinlik, firsat sunarken hızlıca tepki vermeyi de gerektirir (Jütting, Mc Donell ve Osterrieder, 2004, s. 5).

Yerel yönetimler, insanların kendi yeteneklerini ve varlıklarını en iyi şekilde kullanmak için özgürlükler ve firsatlar sunan ortamlar oluşturabilir. Destek sağlayabilir, paydaşlar arasında işbirliğini kolaylaştırabilir ve kırılganlığı azaltabilir. Bununla birlikte, aynı zamanda, yerel yönetimler refahın sürdürülebilir bir şekilde iyileştirilmesini de hedeflemelidir.

Yoksul insanların ihtiyaçlarına cevap verebilmek için, yerel yönetimlerin yoksulluğu azaltma politikalarında sürdürülebilirliği bir öncelik haline getirmesi ve aldıkları kararların bölgedeki insanların refahını nasıl etkilediğinin farkında olması gerekir. Yoksulluğun azaltılması politikaları belli kesimlerin piyasa menfaatleriyle ters düşebilir. Dolayısıyla, bu tür büyük bir endişe 
yaratmamaya çalışılmalıdır. Bütün bu ilkeler eşit derecede önemlidir. Örneğin, orman kaynaklarının hasadının sürdürülebilir olmayan bir şekilde arttırılması, insanlara kısa vadede daha fazla nakit servet kazandırabilir, ancak bu gelir kaynăgı ortadan kalktığında ve daha fazla kazanma imkânı olmadığında onları riske sokar. Örneğin, yiyecek veya barınma yardımı yoluyla kırılganlığı azaltmayı amaçlamak, sürdürülebilirlik ve yeni firsatlar yaratma açılarından ele alınmadıkça, kronik yoksulluğu azaltmayacaktır.

Yerel yönetimlerce yapılan bazı eylemler, yoksullar için daha yüksek getiri sağlamaktadır. Bazı gelişmekte olan ülkelerde yerel yönetimler tarafından desteklenen sağlık ve eğitim hizmetleri, yoksulların haklarının tanınması, altyapının geliştirilmesi, işlere erişim ve istihdam firsatları ve yerel yönetim ile iletişimin geliştirilmesi gibi politikalar yoksullara en yüksek faydayı sağlamaktadır.

Birçok yerde, yerel yönetimler yoksulluğu azaltmak için yerel kaynakları etkin kullanma firsatı sağlamaktadır. Yerel yönetimler, yoksulluğu azaltmak için değerli kaynakları desteklemelidir. Bunu doğrudan yerel ekonomik kalkınma politikaları yoluyla yapabilirler. Yerel yönetimlerin kaynakları kullanma konusunda doğrudan bir yetkisi olmasa bile, kırsal kesimde yaşayan insanların savunucusu olarak görev yapabilir ve diğer devlet kurumlarıyla ilişkilerinde onlara yardım edebilir. Örneğin, yoksul bölgelerden gelen bir talep karşısında sorumlu yetkililerinin, yerel bir kamu kurumu tarafindan yapılan bir toplantıya cevap vermesi daha etkili olacaktır. Ekonomik gelişme ve doğal kaynakların yönetimi faaliyetlerinin yoksulluğu azaltma hedefleriyle tutarlı olmasına özen gösterilmelidir. Yoksulların yararına yönetilebilecek bazı yollar arasında doğal kaynaklara erişimlerinin ve kontrol edilmelerinin sağlanması, yoksulların hakları konusunda eğitilmesi ve pazarın gelişmesini desteklemesi yer almaktadır (Jütting ve ark., 2004, s. 12).

Düzenleyici bir bakış açısıyla, yerel yönetimler tarımsal faaliyetler yoluyla istihdam sağlayabilir. Ayrıca yerel yönetimler ekonomik kalkınma yoluyla yoksulluğu azaltmaya yönelik düzenlemeleri ve çevre sektörler arasındaki düzenlemeleri koordine etmek için lobi yapabilir. Yerel yönetimler, yoksulların ihtiyaç ve tercihlerine uygun politika seçimlerini destekleyebilir (Carter ve Barrett, 2006, s. 190). 


\section{Refahın Farklı Yönleri Arasında Bir Denge Kurmak}

Yerel yönetimler, yoksulluğun birçok farklı yönünü etkileyebilir. Doğal, ekonomik, sosyal ve politik alanlarda ve insanların refahını etkileyen temel koşullar arasında denge kurabilirler. Birçok ülkede yürütülen politikalar yerel yönetimlerin bu farklı alanlarda refahı nasıl etkileyebileceğine dair bazı örnekler sunmaktadır. Birçok yerel yönetim ekonomik kalkınmaya odaklanmak için diğer boyutlara daha az dikkat edebilmektedir. Bunun sebebi, diğer boyutların daha hassas veya daha az görünür olabilmesi ve onlarla nasıl başa çıkılacağı hakkında daha az bilgi sahibi olunmasıdır. Bununla birlikte, sürdürülebilir kalkınmayı sağlamak için tüm kaynakların harekete geçirilmesi zorunludur.

Yerel yönetimlerin yeni oluşturulduğu yerlerde, âdemi merkeziyetçiliğin yoksullara fayda sağlayabileceği ve refahı artırabileceğine dair olumlu işaretler vardır. Bu açıdan ihtiyacı olanlara daha yakın olmak, onları dinlemek ve gelişmekte olan ortaklar olarak görmek ilk adımdır. Ayrıca, yerel yönetimlerin kapasitesini ve profesyonelliğini arttırmanın yanı sıra sürdürülebilirliği tüm alanlarda refahı ele almak ve mekanizmaları geliştirmek için çaba sarf edilmelidir (Batterbury ve Fernando, 2006, s. 1852).

\section{Yoksulluğu Azaltılırken Yerel Kalkınmayı Sağlamak}

Günümüzde yoksulluğun azaltılması "kıt kaynakların yoksullar üzerinde en büyük etkiye sahip olması ve yoksunluk ve kırılganlık seviyelerinin azaltılması muhtemel olan faaliyetlere tahsis edilmesini sağlayacak uygun yöntemlerin tasarlanması, uygulanması ve hedeflenmesi" olarak tanımlanmaktadır. Bunu başarmaya yönelik yaklaşımlar, gelişmenin karmaşıklığına dair derinlemesine anlayışa yanıt olarak son 50 yılda gelişmiştir. 1960'l1 yıllarda bu yaklaşımların birçoğu, fiziksel sermaye altyapısına yapılan büyük yatırımları birincil kalkınma aracı olarak görmüştür. 1970'lerde giderek yaygınlaşan farkındalık düzeyi, fiziksel sermayenin yeterli olmadığını ve en azından sağlık ve eğitim sektörlerinin önemini ortaya koymuştur. Dünya Bankası (1990) bu anlayışı dile getirmiş ve sağlık ve eğitim alanındaki iyileştirmelerin sadece kendi başlarına değil, aynı zamanda yoksul insanların gelirlerindeki büyümeyi de teşvik etmesi nedeniyle önemli olduğunu savunmuştur. Dünya Bankası (1990) bu konuda iki aşamalı bir strateji önermiştir. Bunlar altyapıdaki ekonomik açıklık ve yatırım yoluyla emek yoğun büyümenin teşvik edilmesi ve sağlık ve eğitimdeki yoksul insanlara temel hizmetler sağlanmasıdır. 
Yoksulluğu azaltma çabaları birey, toplum ve ulusal düzeyde gerçekleşir. Son zamanlarda, Yoksulluğu Azaltma Stratejileri birçok ülkede yoksulluğu azaltma planları olarak kabul edilmiştir. Yoksulluğu Azaltma Strateji Belgesi programlarının temelini oluşturan ilkeler, bu tür stratejilerin sürdürülebilir olması için nelerin mevcut bulunması gerektiğini göstermektedir (World Bank, 2003, s. 11-13):

- Formülasyon, uygulama ve sonuçlara dayalı ilerleme ve izleme için geniş tabanlı katılımcı süreçlere dayanan, ülke merkezli kararlar,

- Sonuç odakl1, yoksulun yararına olacak sonuçlara odaklanma,

- Yoksulluğun sebeplerinin çok boyutlu doğasını ve onu azaltmaya yönelik tedbirleri ele alma

- Ortaklık odaklı, kalkınma stratejilerinin (iki taraflı, çok taraflı, hükümet dışı) ülke stratejilerini desteklemeye aktif ve koordineli katılımı için bir temel oluşturmak ve,

- Yoksulluğun azaltılması için orta ve uzun vadeli bir perspektife dayanan stratejileri uygulama.

Her ne kadar ekonomik kalkınma araştırmacıları uzun zamandır yerel yoksulluk ve diğer ekonomik sıkıntıları yerel yönetim faaliyetlerinin belirleyicisi olarak görse de son zamanlarda bu ilişkinin önemini ve anlamını sorgulamaktadırlar. Özellikle diğer topluluk ve devlet faktörlerinin, yoksulluğun etkilerini geçersiz kılma derecesi ve yoksulluğun kendi faaliyetlerini sınırlama konusundaki çalışma şekli tartışmalıdır. Bazı analistler, ekonomik sıkıntıların yerel yönetim faaliyetlerini doğrudan etkilediğini varsayma konusunda araştırmaların aşırı belirleyici olduğunu ve işsizlik gibi sorunların daha az yer aldığını iddia etmektedirler (Goetz, 1994, s. 88).

\section{Yerel Yönetimlerin Yoksulluğa Yönelik Artan Sorumlulukları}

Yerel yönetimlerin, yoksullukla mücadeleye ilgi göstermelerinin birçok nedeni vardır. $\mathrm{Bu}$ nedenler yoksulların demokratik katılım bilincinin geliştirilmesi, bazı kamu hizmetlerinin daha kolay ve pratik sunulabilmesi, merkezi yönetimden kaynaklanan eksikliklerin giderilmesi ve yoksullukla ilgili bilgi ve bilinç düzeyinin artırılması şeklinde sınıflandırılabilir (Önen, 
2010, s. 68). Birçok ülkede yerel yoksulluğu azaltma görevi belediye ve ilçe hükümetlerine verilmiştir. Merkezi hükümet yerel yönetimlere kentsel yoksullara sosyal güvenlik sağlama konusunda sübvansiyon sağlamaktadır (Wang, 2004, s. 9). Yerel yönetimlerin yoksullukla mücadeleye yönelik kapsamı, âdemi merkeziyetçi politikalar, mevcut kaynakları ve bu kaynakları kullanmak için aldığı kararların sağladığı yasal çerçeve ile şekillenir. Yoksulluğa neden olan faktörlerin, eylemler için bir strateji belirleme konusunda yerel yönetimlerden gerçekten etkilenip etkilenmediğini belirlemek önemlidir (Yan, 2018, s. 467).

Büyük şehirlerdeki yoksullar daha büyük sağlık ve çevresel tehlikelerden kaynaklanan tehditlerle karşı karşıya kalmaktadır. Yoksullar ayrıca yetersiz konut, sağlıksız temizlik koşulları, kirli içme suyu ve diğer temel hizmetlerin yetersizliği ile de karşı karşıya kalmaktadır. Birçok yoksul birey, çevresel bozulmaya daha yatkın marjinal bölgelerde yaşamaktadır. 2030 yılına kadar 9,7 milyara ulaşması beklenen dünya nüfusunun \%90'ının şehirlerde yaşayacağı tahmin edilmektedir. Halihazırda kentsel nüfusun büyük bir kısmı, sağlık ve yaşamı tehdit edici koşullar ile gittikçe çürüyen bir kentsel ortamda yaşamaktadır. Şu anda bile en az 250 milyon kişinin güvenli ve sağlıklı suya erişimi yoktur (Wichmann,1995, s. 3).

Yerel yönetimleri yoksullukla mücadeleye yönlendiren ya da bu sorunun giderilmesinde yerel yönetimleri öne çıkaran temel ilkelerin başında "özerklik", "yerinden yönetim", "yönetişim" ve "hizmette yerellik" ilkelerinin geldiği söylenebilir. Bu ilkeler sayesinde yerel yönetimler, yoksulluğa karşı kendilerini daha çok sorumlu ve duyarlı hissederlerken, aynı zamanda yoksul ve yardıma muhtaçyerel halkakarşı daha etkilivekalıcı politikalararacılığıylamücadelelerini daha etkili hale getirebilmektedirler (Önen, 2010, s. 71). Belediyelerin âdemi merkeziyetten yararlanma kabiliyetleri doğrudan, kurumsal düzenlemelere ve finansal desteğe ulaşabilme kapasitelerine bağlıdır. Bu, stratejik uygulama belirleme, çoklu finansman kaynaklarına dokunma, kaynakları kullanma ve program uygulama ve işletiminde genel tutarlılığı sağlamak için yatırım fonlarının akışını koordine etme kapasitesi anlamına gelir.

Küresel ekonomi kentleşmeyi büyük bir hızla tetiklemektedir. Yoksulluk ve çevresel düşüş döngüsü, hızlı bir ekonomik büyüme ve altyapı boşluklarının kapatılmasını gerektirmektedir. Gündem 21'in politika girişimleri yerel şehir düzeyinde gerçekleşmekte ve politikalar insanları doğrudan 
etkilemektedir. Gündem 21'in gelecekteki başarısı, yerel inisiyatiflere bağlı olacaktır. Sürdürülebilir kalkınmayı sağlamak için yönetim yaklaşımlarının değişmesi gerekebilir. Yoksullar seslerini daha fazla duyuracak, daha fazla görünür olacaktır. Kritik yönetim alanları arasında atık yönetimi, kirlilik kontrolü, trafik, ulaşım, enerji, ekonomik gelişme ve iş yaratma yer almaktadır. Toplum, öncelikleri belirlemeye katılabilmelidir. Gündem 21 planlama girişimlerine yaklaşık 1500 yerel makam katılmaktadır. Brezilya'nın Curitiba kenti, şehirlerin toplum sorunlarını nasıl çözebileceğine bir örnektir (Wichmann,1995, s. 3).

Yerelleşme ile ilgili araştırmaların yoksul ve yerel yönetim faaliyetleri için çeşitli etkileri bulunmaktadır. İlk olarak, yoksulluk, merkezi olmayan bir ortamda güçlendirilmiş ve devlet faaliyetlerini doğrudan etkilemesi gereken yapısal bir eşitsizliktir. Yoksulluğun beslendiği ana mekanizma, vatandaşların ihtiyaçları pahasına olsa bile ticari büyüme için baskı oluşturmaktır. İkincisi, yerellerin ekonomik büyümesi ve yeniden dağıtma faaliyetleri arasında bir denge olmalıdır. Ekonomik kalkınma faaliyetlerine yüksek oranda dâhil olan ülkeler yoksul haneler ve dezavantajlı nüfus için daha az hizmet sunabilir. Üçüncüsü, ticari etkiler, büyüme yaratma baskısı altında olan daha yoksul kentlerde daha hissedilir olmalıdır (Lobao ve Kraybill, 2009, s. 420).

\section{Yoksullukla Mücadelede Merkezi/Yerel Yönetim İşbirliği}

Geçtiğimiz yıllarda yoksulluğun azaltılması konusunda belirgin ilerleme kaydedilmiştir. Dünya, 1990'daki yoksulluk oranını 2015'e göre yarı yarıya azaltmak şeklindeki Binyıl Gelişme Hedeflerine ulaşmıştır. Yoksulluğu azaltma konusunda kaydedilen ilerlemeye rağmen, küresel olarak aşırı yoksulluk içinde yaşayan insan sayısı kabul edilemez bir şekilde yüksektir. Küresel büyüme tahminleri gözönüne alındığında, yoksulluğun azaltılması, 2030 yılına kadar aşırı yoksulluğa son verme hedefine ulaşmak için yeterince hızlı görünmemektedir.

Hükümetlerin özel sektöre, bakanlıklara ve yerel yönetimlere, emek yoğun temelli işlerin etkin biçimde planlanması, tasarlanması ve uygulanmasında yardımcı olmak için kılavuzlar sağlamada önemli bir rolü vardır. Ancak, altyapı işlerinin uygulanması öncelikle özel sektör tarafından gerçekleştirilmektedir. Yoğun emek gerektiren yöntemlerin kullanımına ilişkin şartlar sözleşme koşullarında ve iş şartnamelerinde belirtilmelidir. $\mathrm{Bu}$ açıdan kapasite geliştirme de bir zorluktur. Yerel yönetimler, kırsal kesimdeki 
yoksulluğu azaltmak için stratejik bir konumdadır. Yerel yönetimler, kendi bölgelerindeki yoksulluğun kendine özgü doğasını ve bunun azaltılması için ilgili olanakları daha iyi anlayabilirler. Yoksulları doğrudan dinlemek ve onlarla çalışmak için daha fazla firsata sahiplerdir. Çünkü yerel yönetimler genellikle kendi bölgelerindeki diğer kalkınma faaliyetlerini koordine etmekten sorumlu yerel otoritedir.

Âdemi merkeziyetçiliğe ve yerel ekonomik kalkınmaya yönelik geniş yazın, yoksulluğun geleneksel ticari faaliyetlerinin, alternatif ekonomik kalkınma faaliyetlerinin ve haneleri destekleyen hizmetlerin kullanımı üzerinde farklı bir etkiye sahip olabileceğini göstermektedir (Sullivan, 2002, s. 118). Merkezi hükümet, sektör politika ve stratejilerinin, standartların, normların ve kılavuzların geliştirilmesi ve fonların yönlendirilmesi yoluyla altyapının geliştirilmesini etkiler ve destekler. Bu eşgüdümün başarılı örneklerinden birini sunan Endonezya, 2001 yılında bir âdemi merkeziyet süreci başlatmış ve yerel altyapı geliştirme sorumluluklarını yerel makamlara devretmiştir. Bu seviyelerde gerekli kapasiteler genellikle henüz yeterince geliştirilmemiştir ve bu durum ülkedeki altyapının durumunu etkilemektedir. Etkin ve hesap verebilir bir idari ve finansal yönetim için gerekli temel sistemler ile katılımcı planlama ve gözetim için modellerin geliştirilmesine öncelik verilmiştir. $\mathrm{Bu}$ kapsamda, yerel yönetim modelleri tanıtılmış ve farklı sektörlerde teknik beceriler güçlendirilmiştir. Bununla birlikte, kapasite geliştirme konusu da öncelikli bir alan olmaya devam etmektedir (ILO, 2008, s. 3).

Bu konuda yapılan çalışmalarda dikkat edilen nokta yerel yönetim kapasitesinin etkinliğinin yoksullukla mücadelede önemli bir belirleyici olduğu yönündedir. $\mathrm{Bu}$, yerel yönetimlerin, yoksulluğun ve diğer yapısal eşitsizliklerin etkilerini geçersiz kılabilecek yerel kontrol altında bir dereceye kadar kaynaklara sahip olduğunu savunan son yerel ekonomik kalkınma yazınını desteklemektedir (Barrett, 2005, s. 47).

Yoksullukla mücadele etmek için yasal yetkiye sahip bir yerel yönetimin etkili olamamasının birçok nedeni vardır. Hükümet birbiriyle rekabet halindeki çıkarlar, önyargılar veya yolsuzluk gibi nedenlerle siyasi iradeden yoksun olabilir ve sonuç olarak karar verirken yoksulluğun azaltılmasına öncelik vermeyebilir. Hükümetin kaynakları veya personeli yetersizse veya eylem maliyetleri çok yüksekse, etkili davranma kabiliyetinden yoksun olabilir. Genellikle hükümetler yerel yoksulluk hakkında bilgi sahibi 
değildir. Örneğin, yoksulların nerede olduğunu ya da neden yoksul olduklarını bilemeyebilir. Benzer şekilde, yoksulluk hakkında bilgi mevcut olsa bile, yerel yönetim cevap verecek bilgi veya tasarım stratejilerini sentezleme yeteneğinden yoksun olabilir (Narayan ve Petesch, 2002, s. 23).

Bazı durumlarda, yerel yönetim yoksulluğu potansiyel olarak ele alabilir, ancak âdemi merkeziyetçilik politikaları veya ilgili reformlar, yerel yönetimin harekete geçmesi için gerekli şartları veya koşulları sağlamaz. Örneğin, yerel yönetim, mülkiyet haklarıyla ilgili ihtilafları çözmek için topluluklara yardım etme konusunda ilgi gösterebilir veya orman yönetiminin iyileştirilmesine yardımcı olmak için ayrıntılı bilgiye sahip olabilir, ancak orman kaynakları konusunda yetkisi olmadığ 1 için hareket edemez. Devlet kurumları için fon belirleyen yasal çerçeveler vergilerden elde edilen fonları diğer hükümet düzeylerine yönlendirebilir. Böylece yerel yönetimlerin sürdürülebilir orman yönetimini veya hakların eşit şekilde dağıtılmasını teşvik etmede kazanılmış bir çıkarı yoktur. (Jütting vd., 2004, s. 6).

Yerel yönetim politikalarına sıklıkla atıfta bulunulmakla birlikte, reformların genellikle yerel yönetimler üzerinde doğrudan etkiye sahip olabilecek daha büyük politika değişikliği paketleri ürettiği de bir gerçektir. Ulusal rejimlerdeki değişiklikler ve siyasi katılım, ifade özgürlügü, pazarlar, toprak veya ormanc1lıktaki reformlar genel olarak âdemi merkeziyetçiliğe eşlik eder. Yerel yönetimler için mümkün olan her türlü eylemi anlamak için bu politika kümelerinin anlaşılması önemlidir. Ne yazık ki, yeni politikaların etkileri genellikle belirsizdir ve nasıl çalışacaklarını ve boşlukların nerede kalacağını belirlemek için zaman gerektirir. Yerel yönetimlerin yasal zorunlulukları olmadığı durumlarda, yarg1 yetkisine sahip diğer kurumlarla işbirliği yapmaları, politika reformunu desteklemeleri veya sivil toplum kurumları için bir rolü teşvik etmeleri gerekebilir (Önen, 2010b, s. 176).

Yerel yönetimlerin güçlü yetkilere sahip olduğu yerlerde, derhal ve doğrudan harekete geçilebilir. Bu konuda zorunluluğu olmayan ancak yoksullukla mücadele potansiyeline sahip ve daha fazla yetkisi olan diğer gruplarla işbirliği yapılabilir. Yerel yönetimlerin belirli yoksulluk nedenlerini etkileyemeyeceği durumlarda, bu nedenlerin etkilerini hazırlamak veya azaltmak en uygun strateji olabilir. Ancak merkezi olmayan sistemlerin tasarımına rağmen, birçok yoksulluk nedeni yerel yönetimin kontrolü dışındadır. Örnekler arasında doğal 
afetler, bozulmuş kaynaklar veya uluslararası piyasalar tarafindan belirlenen fiyatlar akla ilk gelenlerdir. Bu gibi durumlarda, yerel yönetimin nedenleri doğrudan etkileyemediği açıksa en azından olumsuz etkileri hafifletmek için eylemlere odaklanmalıdır. Yerel yönetimlerin yardım için dış organlara başvurmaları, alternatif ekonomik stratejiler aramaları veya kayılar için tazminat talep etmeleri de muhtemel gereklilikler arasında sayılabilir.

\section{Sonuç ve Öneriler}

Yoksulluğun tanımlanması ve ölçülmesi sorunu, soruna katkıda bulunan farklı faktörler nedeniyle son derece karmaşıktır. Dolayısıyla sorun ekonomik büyümeden daha fazlasını gerektirir. Güçlü ekonomilere sahip "gelişmiş" ülkelerde, hala hayatta kalmak için mücadele eden önemli sayıda insan vardır. Refahı ve yoksulluğu anlamak, yoksulluğu azaltmanın ilk adımıdır. Yoksulluğun nedenlerini, yoksulluğu azaltma hedeflerini ve yapılması gerekenlerin kapsamını belirlemek için anlamlı tanımlar önemlidir. Yerel yönetimler, yerel düzeyde doğru kararlar almalarına yardımcı olacak refah ve yoksulluk kavramlarına ihtiyaç duyarlar. Bu kavramlar, merkezi ve yerel yönetimlerin yoksulluk ve refah arasındaki ilişkiyi daha net anlaması için bir başlangıç oluşturabilir.

Yoksulluk, dünyanın her yerindeki hükümetlerin gündemini işgal etmektedir. Ortaklıklar, katılımcı süreçler ve yerel paydaşlar arasındaki işbirliği, gözden geçirilen yeni girişimlerin temel özellikleridir. Yoksullukla yerel düzeyde mücadele etmede son dönemlerdeki en yaygın eğilimlerden biri, genellikle gecekondu bölgelerinde kümelenmiş yoksul bireylerin yaşam düzeylerini iyileştirmek için yeni programların geliştirilmesidir. $\mathrm{Bu}$ programlar geleneksel doğrudan nakit desteklerinin çok daha ötesindedir. Daha çok sosyal içerme politikaları olarak adlandırılmaları daha uygundur. Nitekim yoksulluğun sadece maddi gelir eksikliği demek olmadığı, doğrudan doğruya bireylerin refah düzeylerindeki ve haklarındaki eksilme anlamına geldiği artık kesin olarak anlaşılmıştır.

Kesin olarak anlaşılan bir diğer nokta ise merkezi hükümetlerin eskiden olduğu gibi yoksullukla tek başlarına mücadele etmesinin artık neredeyse imkansız olduğudur. $\mathrm{Bu}$ nedenle, merkezi-yerel yönetim, özel sektör, ulusüstü örgütler, sivil toplum örgütleri gibi çok sayıda aktörün bir arada ve birbirini tamamlar nitelikte yoksullukla topyekûn 
mücadele etmesi kesin bir gerekliliktir. Ancak, bu tür ortaklıklar savunmasızdır. Ortaklardan birinin veya birisinin çıkarları değiştiğinde, tüm ortaklık çözülebilir ve siyasi destek ve kaynaklardan yoksun bırakılan mükemmel girişimler çökebilir. Ortaklar arasında en yaygın çatışma nedeni politikadır. Sorunların ve liderlikteki süreksizliklerin aşırı politikleşmesi aksamalara yol açabilir. Seçim stratejileri, politik manevra ve yerel makamlar ve ortak kuruluşlar içindeki kişisel çatışmalar kısmi veya tamamen ayrilmaya neden olabilir.

Ancak yine de yerel yönetimlerin yoksulluğu önlemede izleyebileceği bir dizi strateji belirlenebilir. Bu stratejiler şu şekilde sıralanabilir:

- Gecekonduların iyileştirmesi

- Şartlı Nakit Transferleri

- Okula devamla ilgili asgari gelir desteği

- İş piyasasına giriş için mesleki eğitim

- Yoksulların girişimcilik becerilerini geliştirme

- Kayıtdışı çalışanlar için mikro kredi verme

- Okuma yazma bilmeyenler için mesleki eğitim programları uygulama

- Aileyi korumaya yönelik politikalar

- Sokak çocukları için düzenlemeler

- Yoksulluğun azaltılmasında toplumsal cinsiyet odaklı yaklaşımların benimsenmesi

Özetlemek gerekirse, yoksulluk ve yerel yönetimlerle ilgili araştırmalarda yerel yönetim kapasitesinin yoksulluğun önlenmesindeki etkinlik düzeyinin önemli bir belirleyicisi olduğu ortadadır. Bu, yerel yönetimlerin, yoksulluğun ve diğer yapısal eşitsizliklerin etkilerini geçersiz kılabilecek yerel kontrol altında bir dereceye kadar kaynaklara sahip olduğunu savunan son yerel ekonomik kalkınma literatürünü desteklemektedir. Dolayısıyla, yerel yönetimlerin yoksullukla mücadeledeki otonomi düzeylerinin, yetki paylaşımları başta olmak üzere, birçok şekilde desteklenmesi ve arttırılması kesin bir gerekliliktir. 
Hakem Değerlendirmesi: Dış bağımsız.

Çıkar Çatışması: Yazar çıkar çatışması bildirmemiştir.

Finansal Destek: Yazar bu çalışma için finansal destek almadığını beyan etmiştir.

Peer-review: Externally peer-reviewed.

Conflict of Interest: The author has no conflict of interest to declare.

Grant Support: The author declared that this study has received no financial support.

\section{Kaynakça/References}

Ashaver, B. T. (2013). Poverty, inequality and underdevelopment in third world countries: Bad state policies or bad global rules? Journal of Humanities and Social Science (IOSR-JHSS), 15(6), 33-38.

Barrett, C. B. (2005). Rural poverty dynamics: Development policy implications. Agricultural Economics. International Association of Agricultural Economists, 32(1), 45-60.

Batal, S. (2016). Yoksulluk kavramının yerelleşmesi: Kentsel yoksulluk ve yerel yönetimlerin konuya yaklaşımı. International Journal of Social Science, 52, 301-316.

Batterbury, S., \& Fernando, J. (2006). Rescaling governance and the impacts of political and environmental decentralization: an introduction. World Development, 34(11), 1851-1863.

Bonfiglioli, A. M. (2003). Empowering the Poor: Local Governance for Poverty Reduction. New York. UNCDF.

Bradshaw, T. K. (2006). Theories of poverty and anti-poverty programs in community development. RPRC Working Paper No. 06-05. University of Missouri. Columbia.

Carr, E. R. (2008). Rethinking poverty alleviation: A 'poverties' approach. Development in Pratice, 18(6), 36-48.

Carter, M. R., \& Barrett, C. B. (2006). The economics of poverty traps and persistent poverty: An asset-based approach. Journal of Development Studies, 42(2), 178-199.

CPRC. (2004). Chronic Poverty Report 2004-5, Manchester.

Dixon, J., \& David, M. (2002). Poverty: A persistent global reality. London. Routledge.

Domfeh, K. A., \& Bawole J. N. (2009). Localising and sustaining poverty reduction: experiences from Ghana. Management of Environmental Quality: An International Journal, 20(5), 313-336.

Genyi, E. (2008). Poverty, good governance and development process in Nigeria. International Conference on Arts and Humanity. 3rd - 7th November. University of Abuja. Nigeria.

Goetz, E. G. (1994). Expanding possibilities in local economic development policy: An examination of U.S. Cities. Political Research Quarterly, 47(1), 85-109.

Guttal, S. (2007). Globalisation. Development in Practice, 17(4-5), 113-145. 
ILO. (2018). Infrastructure, Poverty Reduction and Jobs, https://www.ilo.org/asia/ projects/WCMS_099513/lang--en/index.htm

Jütting, J., Kauffmann, C., Mc Donnell, I., Osterrieder, H., Pinaud, N., \& Wegner, L. (2004). Decentralisation and Poverty in Developing Countries: Exploring the Impact. OECD Development Centre. Working Paper No. 236. Paris.

Linda L., \& K. (2009). Poverty and local governments: Economic development and community service provision in an era of decentralization. Growth and Change, 4(3), 98-114.

Narayan, D., \& Petesch, P. (2002). Voices of the poor: from Many Lands. Oxford University Press for the World Bank. New York.

Nissanke M., \& Thorbeck E. (2006). Channels and policy debate in the globalizationinequality-poverty nexus. World Development, 34(8). 1338-1360.

Olowa, O. (2012). Concept, measurement and causes of poverty: nigeria in perspective. American Journal of Economics, 2(1), 25-36.

Önen, S. M. (2010). Yerel yönetimlerin yoksullukla mücadelesi: Malatya Belediyesi örneği. Saylştay Dergisi, 21(79), 63-95.

Önen, S. M. (2010b). Yoksulluk ve yerinden yönetim: Nasıl bir yönetişim. Türk İdare Dergisi, 82(469), 165-182.

Rassekh F., \& Speir J. (2010). Can economic globalization lead to a more just society? Journal of Global Ethics, 6(1), 66-87.

Stiglitz J. (2018). Küreselleşme: büyük hayal kırıklı̆̆ (Çeviren: Arzu Taşçığlu, Deniz Vural). İstanbul: Alfa Yayıncilık.

Sullivan, D. M. (2002). Local governments as risk takers and risk reducers: An examination of business subsidies and subsidy controls. Economic Development Quarterly, 16(2), 55-87.

Şenses F. (2001). Küreselleşme sürecinde yoksulluk. İstanbul: İletişim Yayınları.

Todaro, P. M., \& Smith, S. C. (2006). Economic development. Harlow: Pearson Education.

Uzun, A. M. (2003). Yoksulluk olgusu ve dünya bankası. C. ̈̈. Íktisadi ve İdari Bilimler Dergisi, 4(2).

Wang, S. G. (2004). "Poverty Targeting in the People's Republic of China". ADB Institute Discussion Paper. No. 4.

Wichmann, R. (1995). The link between poverty, environment and development. The Political Challenge of Localizing Agenda 21 ”. Countdown, 1(5). 1-4.

World Bank. (2003). World Bank Participatory Poverty Assessment for Niger. Washington. DC

World Bank. (2018). Poverty Statistics. World Bank Group.

Yan, Ei. (2018). Urban poverty, economic restructuring and poverty reduction policy in urban China: Evidence from Shanghai, 1978-2008”. Development Policy Review, 36(4). 92-116. 
